\title{
A GÊNESE DAS ESCOLAS PÚBLICAS DE INSTRUÇÃO ELEMENTAR EM SANTA CATARINA
}

\author{
Leonete Luzia Schmidt \\ Universidade do Sul de Santa Catarina - UNISUL \\ leonete.schmidt@unisul.br
}

\section{RESUMO}

O presente artigo procura evidenciar a gênese da instrução/educação pública elementar em Santa Catarina durante as primeiras décadas do período imperial, principalmente a década de 1850, período este caracterizado por intensos debates sobre a necessidade de escolarização da população. As fontes analisadas foram relatórios do Presidente da Província e do Diretor Geral de Instrução Pública, além de legislação, periódicos, entre outros documentos fundamentais para o entendimento da dinâmica que se implantava, naquele momento, na área da educação escolar em Santa Catarina. Os resultados obtidos possibilitam compreender que a cultura escolar catarinense, naquele período, apresenta traços do liberalismo moderado, característico das primeiras décadas após a proclamação da independência. Ao mesmo tempo em que a instrução é proclamada como necessária, também é sinônimo de perigo. Sendo assim, o ideário era criar escolas diferenciadas, dependendo do grupo social a que se destinaria.

Palavras-chave: Instrução Elementar; Gênese da Escola Elementar Catarinense; História da Educação Catarinense.

\section{HISTORY OF PUBLIC ELEMENTARY SCHOOL EDUCATION IN SANTA CATARINA}

\begin{abstract}
This article aims to highlight the genesis of public elementary school/education in Santa Catarina during the early decades in imperial period, mainly 1850 s, period characterized by intense debates about the need for population education. Analyzed sources was reports from the President of Province and from General Director of Public Instruction, besides legislation and newspaper, among other documents which were analyzed to understand the way school education was then being implemented in Santa Catarina. Findings allowed understanding that school education in that period was undermined by moderate liberalism, characteristic of early decades after proclamation of independence. While education was proclaimed as necessary, it was also synonymous with danger. In this way, the idea was create differenced school; according to the social group it was destined.

Keywords: Elementary School Education; Genesis of Elementary School in Santa Catarina; History of Education in Santa Catarina.
\end{abstract}

\section{INTRODUÇÃO}

Na ebulição de pensamentos e ideias do século XIX, o novo era anunciado e contrastava com vínculos mantidos com a velha ordem. Esta herança portuguesa é percebida no espaço concedido à religião católica e sua influência em todas as instâncias sociais, na política de clientela favorecedora de pequena parcela da população; aquele, 
inspiração das nações "civilizadas"1, se traduz no ideário liberal, que anunciava maior participação política e o fim de privilégios restritos à minoria. Como os personagens da vida pública de Santa Catarina, que navegaram pelo chamado "Século das Luzes"2, traduziram os ideais da educação? Nos relatórios anuais apresentados à Assembleia Legislativa, os presidentes da Província argumentavam sobre a necessidade de difundir a educação ao maior número possível de homens. Por que essa necessidade se colocava?

Para responder a estes questionamentos, procurou-se conhecer a gênese da escola de primeiras letras em Santa Catarina. Foi necessário, então, reconstruir sua história durante as primeiras décadas do período imperial, principalmente, a década de 1850, dado que é neste período que a estrutura física, pedagógica e legal dessas escolas começa a ser definida pelo Estado.

As principais fontes analisadas são documentos oficiais, como cartas, ofícios, relatórios do Presidente da Província e do Diretor Geral da Instrução Pública, legislação e periódicos encontrados no Arquivo e na Biblioteca Pública do Estado. Além destas fontes, também notícias de jornais sobre a instrução pública foram constantemente utilizadas e contrapostas aos documentos oficiais. Tais fontes, como qualquer documento, contêm uma riqueza de informações que carecem ser transformadas em conhecimento da História. Segundo Thompson,

o objeto imediato do conhecimento histórico (isto é, o material a partir do qual esse conhecimento é aduzido) compreende 'fatos' ou evidências, certamente dotados de existência real, mas que só se tornam cognoscíveis segundo maneiras que são, e devem ser, a preocupação dos vigilantes métodos históricos", o que "consiste num diálogo entre conceito e evidência, um diálogo conduzido por hipóteses sucessivas, de um lado, e a pesquisa empírica, do outro ${ }^{3}$.

As evidências presentes nas fontes analisadas possibilitaram realizar uma leitura sobre o processo de criação e organização das primeiras escolas de primeiras letras em Santa Catarina, ou seja, conhecer a gênese dessa escola.

\section{AS ESCOLAS PÚBLICAS DE INSTRUÇÃO ELEMENTAR PARA MENINOS E MENINAS NA PROVÍNCIA DE SANTA CATARINA}

O processo de criação e organização das escolas públicas de instrução elementar em Santa Catarina certamente ocorreu de forma semelhante às demais províncias brasileiras, obedecendo, evidentemente, às características e condições locais.

Inicialmente, a organização das escolas de primeiras letras deu-se com base em leis imperiais editadas em 1827. A partir de 1834, conforme determinação do Ato Adicional à Constituição de 1824, a instrução primária e a secundária passaram a ser de responsabilidade das províncias. Estas, de acordo com Haidar (1972), trataram de colocar em prática as determinações do Governo Geral, criando, de acordo com suas condições e interesses, escolas primárias e secundárias. Na Província catarinense, os dirigentes também lançaram mão de dispositivos legais para a definição do que deveria ser a escola naquele período.

Em Santa Catarina, a primeira lei provincial sobre instrução primária data de 1835. Nela são reproduzidos alguns artigos da Lei Imperial de 15 de outubro de 1827. A esta lei sucederam, até 1860, outras cinco, além de uma resolução e do Primeiro Regulamento de 
Instrução Primária. Além delas, foram editadas algumas leis específicas que modificaram ou revogaram artigos das anteriores, numa tentativa de adaptá-las às novas demandas sociais, e uma delas especialmente para atender à demanda de contratação de professores para as escolas nas colônias alemãs ${ }^{4}$ (Ver quadro anexo com síntese das principais leis do período).

Deste conjunto de leis, a Resolução de 1854 e o Primeiro Regulamento de Instrução Primária são os dois dispositivos de "normatização" que apresentam elementos definidores da organização e funcionamento da educação escolar elementar.

A Resolução de 1854, composta por 90 artigos, parece que representou esperança de melhoria da escola de primeiras letras, a ponto de o Presidente da Província, João José Coutinho, que esteve à frente da administração de 1850 a 1859 , justificar, no início de 1855, que ainda não podia avaliar os resultados porque a Lei $\mathrm{n}^{\circ} 382$ “[...] principiou a ter execução em janeiro deste ano, e por isso ainda não se pode avançar se ela satisfaz o que tiveram em vista seus autores",

Dentre os aspectos regulamentados nesse dispositivo estão o provimento das Cadeiras, regras para ingresso do professor no magistério e suas obrigações, procedimentos para a realização de exames dos alunos, organização do tempo e espaço e os castigos, a criação dos cargos de diretor e subdiretor em substituição aos diretores municipais e paroquiais.

A inspeção, papel desempenhado a partir desta Resolução, pelo diretor geral e subdiretores, tinha lugar de destaque dentro das funções relacionadas à instrução pública no período. Nas falas oficiais do presidente e dos deputados em artigos nos jornais da época, a responsabilidade pela precariedade do ensino era atribuída à falta de inspeção adequada às escolas e professores.

O diretor era responsável pelos encaminhamentos, cobranças, punições e orientações para professores, além de servir de vínculo entre a escola e o governo provincial. Com a inspeção, o governo buscava controlar todos os movimentos empreendidos na escola e conduzi-la a seu modo por meio das orientações aos professores. A Resolução $\mathrm{n}^{\circ} 382$, de $1^{\circ}$ de julho de 1854 , estabeleceu que houvesse um diretor-geral para as escolas de instrução pública e tantos subdiretores quantos fossem necessários. Estes seriam nomeados e demitidos livremente pelo Executivo.

A relevância da inspeção era tal, que no jornal $O$ Cruzeiro do Sul $(1858$, p. 8) foi escrito um artigo que comparou a função do inspetor geral ${ }^{6}$ à da seiva numa árvore:

A instrução é uma árvore, cujos ramos se esgalham do tronco, que é por assim dizer a base ou a substância dessa mesma árvore [...]. A raiz desta árvore é o governo geral: o tronco é o governo provincial: os galhos com as suas folhas são os diversos ramos da instrução, personificados nos professores e discípulos; a seiva que alimenta esta árvore, desde a raiz até a última folha é o inspetor-geral. Já se vê, pois, de que importância é a função do inspetor-geral num sistema qualquer de instrução ${ }^{7}$.

No referido artigo, além de mostrar a importância atribuída à função do diretor geral na instrução, o editor demonstra como era, em sua visão, o "sistema de ensino" da época. O Presidente da Província funcionava (ou deveria funcionar) como elo entre o Governo Geral e os núcleos populacionais dos municípios. Estes últimos representados pelos professores, famílias e alunos, todos nutridos pelo Diretor Geral, que levava as informações para os envolvidos no processo. 
Contudo, a inspeção não assegurava o funcionamento de qualidade às escolas conforme anunciado nos discursos. Em 1859, no retorno a Desterro, depois de ter visitado as escolas de primeiras letras de alguns municípios, o Diretor Geral de Instrução Pública, Sérgio Lopes Falcão, apresentou um relatório ao Presidente da Província descrevendo cada escola nos seus diferentes aspectos. Segundo ele, o quadro das escolas públicas na Província encontrava-se pouco satisfatório devido à inexistência de prédios adequados, até a falta de subdiretores competentes e, principalmente, falta de professores qualificados. Observou em seu relatório (1859):

Tem o corpo legislativo provincial procurado e tem sido solícito em estabelecer e criar os meios pelos quais melhor se organize e prospere a instrução elementar, porém por mais que tenha feito, não tem ela em seus progressos correspondido por certo a sua solicitude - Defeitos e defeitos mui graves a isso obstam: ou melhor, ela paira sobre elementos tais que em si mesmos já encerram o definhamento e aniquilação ${ }^{8}$.

Dados do mesmo relatório são citados pelo presidente João José Coutinho quando descreve a situação da instrução na província em seu relatório anual. Neste consta que, dos 1.207 alunos matriculados nas escolas masculinas, realizaram o exame e foram aprovados apenas 37, e das 422 meninas matriculadas em escolas femininas, apenas 13 realizaram o exame e foram aprovadas ${ }^{9}$. Mesmo que as informações dessem conta de que havia um conjunto de fatores contribuindo para a precariedade dos resultados na instrução pública elementar, ainda assim, à inspeção era creditada a solução de todos os problemas.

Com relação ao professor, este deveria ser exemplo de virtude, de moral, de religiosidade, de patriotismo e de civilidade, como prescrito nas determinações dos Artigos $8^{\circ}, 34$ e 73, da Resolução de 1854. Os pretendentes a uma vaga, a partir da Lei Provincial $\mathrm{n}^{\mathrm{o}} 35$, de 14 de maio de 1836 , teriam que se submeter a concurso público, pelo qual seriam avaliados em conhecimentos específicos sobre conteúdos a serem ensinados às crianças e sobre sua conduta.

Para participar do concurso das Cadeiras de Primeiras Letras era necessário ser cidadão brasileiro e estar de posse de seus direitos políticos. O concurso deveria ser anunciado em editais com antecedência de dois meses. $\mathrm{O}$ exame seletivo era público, realizado na Câmara Municipal da Capital, na presença do Presidente da Câmara e de um ou mais vereadores. Os concorrentes eram examinados por três pessoas escolhidas pelo Presidente da Província, e deveriam ter conhecimento das matérias exigidas para a Cadeira vaga. A avaliação era individual, durando meia hora com cada examinador. Cabia ao Presidente da Província dar o parecer final após o resultado do exame e a classificação, ambos assinados pelos examinadores, Presidente da Câmara e vereadores presentes ${ }^{10}$.

O concurso era realizado sempre que vagasse uma Cadeira ou uma nova escola fosse criada. Houve anos em que foram realizados vários concursos em Santa Catarina. Nos relatórios da Câmara Municipal da Capital, encontramos cópias de editais de concurso e de outros documentos que comunicavam quando havia Cadeiras vagas. Exemplo disso é a circular do Presidente da Província, José Joaquim Machado de Oliveira, encaminhada às Câmaras Municipais, em 1837, que diz:

Achando-se por prover as Cadeiras de primeiras letras das freguesias de São João de Imaruí, e Nossa Senhora da Piedade do Município da Laguna, e da freguesia da Enseada do Brito do Município de São José, e da vila de Lages; V.M. na forma do que prescreve o art. $2^{\circ}$ da Lei Provincial $\mathrm{n}^{\circ} 35$ de 14/05/1836, farão afixar editais em todos os distritos desses municípios no dia 15 de junho deste ano, publicando que estão a 
concurso as mencionadas Cadeiras (...) e que o concorrente ou concorrentes devem apresentar-se no dia 16 de agosto futuro na sala das sessões da Câmara Municipal da Capital, onde serão examinados [... ${ }^{11}$.

Em agosto, nova circular foi encaminhada às Câmaras solicitando que colocasse editais anunciando a existência de Cadeiras vagas. Em dezembro houve outro edital, o que significa que em 1837 ocorreram três concursos públicos para professores de primeiras letras.

Em 1854, pela Resolução 382, apareceram exigências não mencionadas nas leis anteriores: para ser admitido em concurso o pretendente deveria comprovar cidadania brasileira, ser maior de 21 anos, ter bons costumes e saúde, professar a religião do Estado e ter pelo menos dois meses de residência na Província.

Uma vez aprovados e assumindo uma Cadeira, os professores tornavam-se vitalícios, o que, para o presidente Coutinho, era um problema:

A vitalicidade do provimento, e a dificuldade de em juízo provar-se-lhes as faltas, dando-lhes bem fundadas esperanças de não perderem o emprego, os torna desleixados. Em geral os discípulos que frequentam as aulas particulares, ou as interinamente providas aproveitam muito mais que os que frequentam as aulas regidas por professores vitalícios. Estes contam seguro o ordenado; aqueles temem que os discípulos os abandonem, e percam uns a Cadeira, e outros as mensalidades ${ }^{12}$.

Ao que parece, o não cumprimento das tarefas pelos professores não estava relacionado apenas à vitaliciedade do cargo, mas, principalmente, à falta de formação e de condições materiais nas escolas.

Aos professores regentes de escolas masculinas de primeiras letras competia ensinar a ler, escrever as quatro espécies em inteiros, frações, complexos, decimais, proporções geométricas diretas, inversas e compostas, gramática da língua nacional e doutrina cristã. As professoras das escolas femininas deveriam ensinar a ler, escrever as quatro espécies em inteiros, gramática da língua nacional, doutrina cristã e as prendas domésticas necessárias à boa educação feminina ${ }^{13}$. Como o professor ou a professora poderiam dar conta de tais conteúdos, sendo eles leigos?

Somado a esses saberes voltados à formação intelectual ou ao desenvolvimento da razão, era preciso, também, despertar nas crianças e nos adolescentes que frequentavam as escolas princípios morais e religiosos e de amor às instituições do Estado. Isto poderia ser conseguido com práticas pedagógicas, também determinadas na Resolução, na qual estava decidido que, aos sábados, os professores deveriam ensinar doutrina cristã e levar os "discípulos" à missa, ensinando-lhes "[...] o modo de ajudar e ouvir" ${ }^{14} \mathrm{e}$, além disso, deveriam fazer

com que seus discípulos se tratem com urbanidade, e que não usem de palavras, gestos, sinais e pinturas indecentes ou obscenas [...] e quando explicarem a Gramática, procurarão usar de orações que envolvam um sentido moral; e inspirarão aos discípulos sentimentos de Religião, virtude, e amor às instituições do Estado ${ }^{15}$.

A escola projetada na Resolução de 1854 contempla, ao mesmo tempo, questões educativas e de instrução. As primeiras são responsáveis pela formação do coração, da moralidade e das virtudes, ou seja, dos hábitos e modos de vida das crianças, por meio de referenciais civilizatórios e de sentimento religioso; e as segundas, pelo desenvolvimento 
de habilidades como ler, escrever e contar. De acordo com Schafascheck (1997, p.70), jornais desterrenses da década de 1850 chamavam a atenção para a necessidade da religião e de princípios morais na formação das crianças. Explicita a autora que o jornal $A$ Revelação (1852) "[...] propagava a ideia de que, sem a moralidade e a religião, não poderia haver uma vida normal e harmoniosa". Diz, ainda, que o jornal O Cruzeiro do Sul (1858) informava que, "[...] desde que o mundo é mundo até hoje, desde o rico até o pobre, a razão sem Deus produz só orgulho e mal!".

Tal entendimento presente no dispositivo de "normatização" da escola primária catarinense, na década de 1850, da necessidade de educar e instruir as crianças, está relacionado com o pensamento ilustrado e liberal dos anos de 1820 e de 1830 que, de acordo com Hilsdorf (2005, p. 43), é de fundo racional e religioso:

Combinados, os traços mentais de pragmatismos das Luzes e de liberalismo filantrópico resultaram em um movimento de assistência e educação das massas com duas marcas: ser ativo, no sentido de ir ao encontro das necessidades da população, e ser de responsabilidade pública, ao invés de atribuição das igrejas.

No jornal O Argos, de 1857 (apud SCHAFASCHECK, 1997, p. 129), há um artigo bastante ilustrativo sobre o que oferecer nas escolas sem comprometer o modelo de sociedade almejada, naquele momento, pela elite dirigente do País. Neste artigo, o editor alega que a instrução não é tão necessária ao povo quanto a educação:

[...] o que um povo há mister não é tanto de uma vasta instrução como de uma boa educação, porque afinal de contas a instrução há de ser sempre limitada para o grandiosíssimo número, e esta difusão igual de meia dúzia de noções elementares não tem evidentemente nenhum dos gérmens que produzem os grandes séculos e os grandes gênios [...]. A educação deve ser popular no sentido que todos os indivíduos carecem de educação; e que a instrução desligada da educação pode levar facilmente um povo ao abismo da barbaridade, ou corrupção, isto é, ao regimen da força bruta, ou da imoralidade ${ }^{16}$.

Percebe-se que para haver ordem e progresso, ou seja, para o país alcançar a condição de civilizado, era preciso que o povo tivesse um mínimo de polimento, e isto a escola poderia oferecer, desde que voltasse sua prática mais para educação do que para a instrução das crianças.

Nesse projeto educacional/instrucional não só os saberes e práticas dos professores são normatizados pelo Estado, como também o tempo escolar passa a ser questão regulamentada.

Segundo a Resolução de 1854, os professores deveriam lecionar “[...] duas vezes por dia das 8 às 11 horas da manhã, e das 2 às 5 horas da tarde nos meses de março a outubro, e das 3 às 6 horas nos de novembro a fevereiro". Além disso, o Presidente da Província poderia ordenar "[...] que nas escolas das Freguesias e Arraiais, em que julgar conveniente, o tempo diário de estudo seja preenchido só de manhã [e os professores deveriam] estar as horas marcadas nas Aulas, vestidos com decência, e conservar com limpeza a casa e utencis" $"$.

O tempo, que até então não tinha maior expressão, ou não era tomado como preocupação, nesse novo modelo de sociedade, onde o urbano e o industrial passam a ser vislumbrados como ideal de civilização, passa a ser elemento regulador da vida das pessoas. 
Além dos horários de entrada e saída, o tempo também se apresenta como questão nas definições de exames e classificações e vai se constituindo em mais um elemento de legitimação da forma escolar que está sendo construída na Província.

O primeiro Regulamento de Instrução Primária, criado em 1859, diferentemente da Resolução de 1854, que definiu aspectos da organização da escola como localização, professores, carreira, inspeção, metodologia, definiu aspectos como: tempos, espaços, sujeitos, saberes a serem ensinados e modos como deveriam ser ensinados ou, conforme mencionou o Presidente da Província da época, em seu relatório anual, "[...] trata especificamente de questões do funcionamento interno das escolas" ${ }^{18}$.

Espaços, tempos, conteúdos, mesmo que rudimentares, devido à fragilidade da escola do período, representavam ideais civilizatórios e zeladores das hierarquias existentes. Neste sentido, é ilustrativo um texto publicado no jornal A Revelação (1853, p. 130) sobre a importância da escola para a população e a necessidade de controle sobre a educação:

As escolas elementares arrancam a vadiíce, e a ociosidade os rapazes desvalidos; e não só ali se lhes inspiram sentimento de piedade e religião, infundindo-lhes ideias de ordem e aplicação, como se lhes desenvolvem ao mesmo tempo as faculdades intelectuais [...]. As crianças que frequentam as escolas são as que melhor aprendem o catecismo, estando aptas, quando crescem, para atenderem o Evangelho, e outros livros ao alcance da inteligência popular. A leitura dessas obras influindo muito nos costumes é, além disso, mui própria para afugentar os vícios que consigo traz a ociosidade. Tais são os resultados da instrução primária prudentemente dirigida.

Durante a década de 1850, é possível perceber que o lugar da escola na sociedade começava a ser produzido, designando-se a ela funções distintas daquelas desempenhadas em outros espaços sociais, como igreja e família. Ela passava a ser vista como indispensável para o desenvolvimento do Estado Nacional moderno, em que o modelo urbano vai superando o rural como modelo de civilização, pois auxiliaria na formação de um novo sujeito, capaz de "[...] legislar, julgar e executar as leis" (grifo nosso).

Neste período, a província catarinense também adquire as primeiras casas para servir de escolas de instrução elementar, bem como as primeiras mobílias padronizadas para este fim. Uma delas, situada no município de Tijucas, em 1857; outras duas em Joinville, no ano de 1858. A aquisição foi necessária, segundo o presidente, em virtude do alto preço do aluguel e, mesmo assim, essas casas, muitas vezes, não atendiam aos fins pretendidos.

Com relação à mobília, no ano de 1855 , o presidente João José Coutinho autoriza o diretor geral interino a comprar ou mandar construir mobília padronizada para algumas escolas de primeiras letras. Compunham essa mobília escrivaninhas de 18 palmos de comprimento e um e meio de largura e bancos com o mesmo comprimento; uma mesa de seis palmos de comprimento e quatro de largura, com gavetas, e uma cadeira para uso do professor $^{19}$.

Além da mobília, faziam parte dos utensílios os livros e outros materiais utilizados nas escolas primárias. De modo geral, assemelha-se ao que consta da lista solicitada pela professora da escola feminina da Trindade, município de Nossa Senhora do Desterro, no ano de 1855 , conforme citada a seguir.

Para uso do professor 
1 livro de 100 folhas, pautado, para matrícula

1 dito de 5 folhas, pautado, para turnos

1 par de tinteiro de chumbo

1 campainha de metal branco

1 canivete de aparar penas

1 régua grande

Para uso de alunos pobres

12 gramáticas de Coruja $8^{\mathrm{a}}$ Edição

12 aritméticas de Coruja

12 catecismos de Montepellier

12 cartilhas de doutrina cristã de Pimentel

12 lousas

12 silabários de letra de mão litografados

12 silabários de letra itálica e romana impressos

12 réguas pequenas ${ }^{20}$.

A partir destes elementos, pode-se fazer uma ideia da escola primária catarinense naquele período. Algumas casas passavam a ser utilizadas especificamente como lugar de aula ou eram escolas. Entretanto, a maioria delas funcionava em um dos cômodos da casa do professor, contendo bancos e mesas para os alunos, uma mesa com gaveta e uma cadeira para o professor ou professora. Além disso, o professor dispunha de uma campainha para anunciar o início e o intervalo da aula, canivete para aparar as penas, um par de tinteiros, uma régua, também o livro de matrícula e outro para registro do andamento das aulas e das ocorrências que viessem a ser registradas durante o ano letivo. Os alunos possuíam livros de diferentes disciplinas, lousas, silabários e réguas.

\section{EDUCAR, INSTRUIR, CIVILIZAR: QUAL O PAPEL DA ESCOLA DE INSTRUÇÃO} ELEMENTAR?

A partir da independência política do Brasil, a educação escolar torna-se questão de Estado e ganha, gradativamente, mais espaços nas discussões dos dirigentes do País. A ideia propagada na época era que da instrução dependiam os progressos civilizadores, materiais e políticos de uma nação. Assim, a instrução era considerada peça fundamental na construção do Estado Nacional brasileiro com perspectivas de vir a ser um país desenvolvido, como os europeus. Sob esta ótica, sentenciava o jornal desterrense $O$ Conservador (1855, p. 3):

O século atual é de progresso: o amor às letras, à animação, à indústria e às artes, à luta entre a tirania e a liberdade; eis os elementos que constituirão o quadro filosófico desta época, que certamente prepara o homem à conquista para a civilização.

O processo de escolarização estava vinculado à afirmação e ao fortalecimento dos Estados Modernos. No Brasil oitocentista, o processo de escolarização foi um dos elementos centrais na afirmação do Estado Imperial.

Em Santa Catarina era comum aparecer, nas páginas de jornal da época, nos relatórios de presidente de província, de diretores de instrução pública, entre outros relatos de dirigentes do período, um discurso civilizatório e legalista, sempre articulado à necessidade de instruir o povo. Conforme artigo publicado no jornal O Cruzeiro do Sul 
(1858), "[...] a mais imperiosa necessidade administrativa de que se ressente o Brasil, é inquestionavelmente a organização sistemática da educação e da instrução" ${ }^{21}$. No mesmo artigo, o editor do jornal afirmava que "[...] os presidentes das províncias, e as respectivas assembleias têm buscado corresponder a esta legítima exigência de um povo civilizado; mas tão generosos esforços têm sido estéreis e improfícuos na prática".

A educação era vista pelos dirigentes como um caminho para a concretização de uma nova política para o País, pois, por meio dela, a população poderia ser envolvida nos interesses do Estado:

O grupo no poder necessitava construir sua hegemonia, vendo-se constantemente ameaçado, de um lado, por revoltas que ocorriam do nordeste ao sul do país e, por outro lado, pela indiferença de grande parte da população para a qual Pátria nunca existiu. [...] o ideal de civilidade requeria uma sociedade formada por indivíduos unidos pelo governo central e pela lei (SCHAFASCHEK, 1997, p. 63).

O presidente da Província, João José Coutinho, em seus discursos, também mostrava estar articulado a esse pensamento. Ao completar dois meses à frente da administração, por ocasião da abertura da primeira sessão da Assembleia Legislativa, na fala que dirigiu aos deputados, reclamava do pequeno orçamento destinado à instrução pública:

Se se quiser, como entendo indispensável, dar aos meninos, além do conhecimento das primeiras letras, alguma educação, é necessário que as casas tenham acomodações adequadas às suas precisões. Se para as satisfazer eles tiverem que sair à rua, não só perderão grande tempo de estudo, como mais facilmente praticarão atos d'imoralidades (1850, p. 6).

A escola, além de ser espaço para as crianças adquirirem conhecimentos específicos das diferentes áreas, também, e principalmente, era espaço de difusão de valores morais e religiosos para formação de uma "civilidade", questão indispensável para o desenvolvimento. "Civilizar a população era 'conceder' cidadania, entendida como direito civil de reconhecer-se como brasileiro, pertencente a uma cidade, sujeito a leis e não a vontades individuais e particulares" (SCHAFASCHERK, 1997, p. 64).

Pelos jornais que circulavam na cidade, editores, que geralmente eram integrantes da mesma elite que compunha os quadros do governo provincial, opinavam sobre a instrução mais apropriada para os pobres e para os ricos. No jornal O Mensageiro (1856, P. 3), de tendência liberal, publicado em Desterro na década de 1850, há um texto ilustrativo referente a esta questão:

Quando desejamos, por exemplo, que os homens destinados para a lavoura, para as artes fabris, para os vários misteres da sociedade saibam ler, não queremos que eles se habilitem para ler muitos livros, para gastar nisso a vida, para serem grandes letrados: não pretendemos encher o mundo de sábios e eruditos. [...] o nosso fim é tão somente que cada indivíduo tenha os meios de empregar com maior proveito seu e da sociedade, as faculdades que Deus lhe concedeu; [...] os meninos que frequentam as escolas elementares, terão desde logo a grande utilidade de livrar-se da ociosidade, da distração e dissipação do espírito dos perigos de uma vida vaga e desocupada, da inclinação ao jogo e aos folguedos tumultuosos daquela idade. [...] a simples instrução de ler, escrever, e contar para os meninos pobres, desenvolve suas faculdades e lhes dá um 
certo grau de cultura moral. Os meninos que frequentam a escola dão o primeiro passo para o amor da religião (grifos do autor).

Essa distinção entre a educação do rico e a do pobre apresentada no jornal é representativa da mentalidade ilustrada e liberal dos dirigentes do País nas primeiras décadas após a Proclamação da Independência do Brasil. Conforme Hilsdorf, os traços dessa mentalidade "[...] são responsáveis por um movimento racionalista em direção às massas, com duas características - uma responsabilidade pública, em vez de atribuição exclusiva das Igrejas, e ser ativo, no sentido de ir ao encontro dos pobres e infelizes para assisti-los e educá-los" (HILSDORF, 2001, p. 70).

A preocupação com a preservação da ordem social estabelecida criava a necessidade de difundir a ideia, entre a população, das vantagens de uma escola diferenciada para os pobres, como pode ser visto em outra parte do mesmo artigo:

Temos visto pessoas, aliás sensatas, recear a propagação do ensino popular, por um bom estranho motivo. - Dai educação (dizem eles) ao filho do artífice, de um agricultor: ele deixará logo a profissão de seu pai. Quando a instrução se fizer comum, ninguém quererá exercer ofícios humildes e laboriosos. Se um homem rico (por exemplo) chamar a sua casa o filho do seu feitor, ou de um oficial pobre, o mandar educar com seus próprios filhos, o fizer trajar vestidos ricos e preciosos, lhe fizer aprender as línguas cultas, e as artes do luxo, naturalmente parece que o menino venha por tempo desdenhar o estado, a vida, o ofício do seu pai, que lhe seja penoso e repugnante lançar mão à enxada; que se não julgue igual, mas superior aos seus vizinhos, e até que venha a desejar e a pretender empregos elevados. Mas se aquele homem rico deve ter uma generosidade mais ilustrada; se em lugar de dar ao menino pobre uma educação brilhante, mas perigosa, estabelecer na sua Aldeia uma escola elementar, a que possam concorrer todos os meninos pobres, onde não se ensine estudos supérfluos, mas que recebam princípios religiosos, ideias e máximas morais, regras de bons e virtuosos costumes; todos aprenderão a ler, escrever e contar. Todos respeitarão as leis civis, religiosas e obrigações domésticas: nada os incitará a abandonar o ofício de seus pais, nada concorrerá para alterar essa igualdade que se deseja conservadora (O MENSAGEIRO, 1856, p. 3).

Escola era necessária, mas teria que ser diferenciada para as crianças pobres, pois o conhecimento poria em xeque a permanência delas ao lado dos seus e as levaria a reivindicar posições até então asseguradas a determinado grupo. A insegurança em relação à perda de privilégios fazia com que liberais e conservadores tivessem entendimento semelhante quanto ao tipo de educação escolar oferecido às crianças.

Para esse editor, a educação proveitosa e perfeita deveria estar adaptada a cada povoação e a cada nível social. Sendo assim, a escola poderia e deveria existir, mas, quando fosse direcionada à população pobre, seria muito mais um espaço de formação de princípios morais, éticos, religiosos, do que um local de aprendizagem de conteúdos. As crianças que passassem pela escola deveriam aprender a respeitar as instituições do Estado, a pessoa do Imperador, as leis do Império e os princípios morais vinculados à religião católica.

Esses princípios anunciados eram garantidores da ordem e da tranquilidade pública, suficientes, portanto, para os pobres. Daria a eles a noção de onde viviam, a quem deviam obediência e respeito e que valores morais e éticos seguir. Outros conhecimentos 
deveriam ser destinados a poucos, àqueles que precisavam de uma educação distinta para seguir carreira especial, conforme outro jornal publicava:

[...] diversas são as profissões que os homens abraçam, e daí vem que a educação divide-se forçosamente em científica e em popular. A educação popular abrange quase todas as classes da sociedade, e todos os conhecimentos que competem à maioria dos cidadãos, é por isso a mais importante. A científica ou literária é só para limitado número dos que seguem carreiras especiais (A REVELAÇÃO, 1852, apud SCHAFASCHECK, 1997, p. 132).

Segundo Schafascheck (1997, p.132), “[...] o advento da ciência anunciava a possibilidade de progresso e, ao lado deste, colocava-se para a elite a necessidade de conservar a ordem. A partir daí, propunha-se a dualidade do ensino como garantia de generalização da instrução com manutenção das desigualdades".

Finalmente, cumpre dizer ainda que, embora a escola de primeiras letras oferecida às crianças pobres se limitasse ao ensino elementar da leitura, escrita e contas das quatro espécies e da formação de valores morais e éticos, ela começava a ser reclamada por pais que se ressentiam da sua falta na educação dos filhos. Não só o Estado e professores, mas também outros atores sociais demonstravam interesse pela educação escolar. A ideia de que era possível "nascer sapateiro e morrer ministro", menção à política liberal que apareceu nas páginas dos jornais desterrenses da época, cria a necessidade da escolarização entre a população, embora, na prática, a característica dualista da escola assegurasse à maioria da população apenas o "verniz das luzes", e aos demais uma formação intelectual que abria caminhos para o prosseguimento nos estudos e a ocupação dos quadros políticos e burocráticos do Estado $^{22}$.

\section{Referências}

BASTOS, Maria. H. O ensino mútuo no Brasil (1808-1827). In: BASTOS, Maria Helena; FARIA FILHO, Luciano Mendes de (Org.). A escola elementar no século XIX: o método monitorial/mútuo. Passo Fundo: EDIUPF, 1999. p. 95-118.

FARIA FILHO, Luciano. M. de; VAGO, T. M. Entre relógios e tradições: elementos para uma história do processo de escolarização em Minas Gerais. In: VIDAL, Diana Gonçalves; HILSDORF, Maria Lúcia Spedo (Org.). Brasil 500 anos: tópicos de história da educação. São Paulo: Edusp, 2001.p.117-136.

HAIDAR, Maria de Lourdes Mariotto. O ensino secundário no império brasileiro. São Paulo: EDUSP. 1972.

HILSDORF, Maria Lúcia Spedo. Cultura escolar/cultura oral em São Paulo (1820-1860). In: VIDAL, Diana Gonçalves; HILSDORF, Maria Lúcia Spedo (Org.). Brasil 500 anos: tópicos de história da educação. São Paulo: Edusp, 2001. p.67-96.

HILSDORF, Maria Lúcia Spedo. História da educação brasileira: leituras. São Paulo: Pioneira Thompson Learning, 2005.

SANTA CATARINA. Jornal O Conservador, n. 315, p. 3, c.1, 17-4-1855. . Jornal O Mensageiro, de 23 de fevereiro de 1856. 
. Jornal O Cruzeiro do Sul, nº 2, p.2, de 11 de março de 1858.

. Coletânea de Leis Provinciais de 1835 a 1860. Florianópolis, Arquivo Público do Estado de Santa Catarina.

. Resolução n. 382 de 1\%07/1854 - BPESC.

Primeiro Regulamento da Instrução Primária de 05/05/1859 - APESC.

. Correspondências de diversos ao Presidente da Província - APESC.

1855 - 1860 - APESC.

Ofícios do Diretor da Instrução Pública ao Presidente da Província, 1855 - 1860 - APESC.

Registros do Presidente da Província à diretoria da Instrução Pública - Relatórios do Diretor Geral da Instrução Pública ao Presidente da Província, 1855 - 1860 - APESC.

- Relatórios do Presidente da Província apresentado à Assembléia Legislativa de Santa Catarina - 1830 - 1860 - APESC.

SCHAFASCHEK, Rosicler. Educar para civilizar e instruir para progredir: análise de artigos divulgados pelos jornais do Desterro na década de 1850. 1997. 154 p. Dissertação (Mestrado em Educação) - Universidade Federal de Santa Catarina, Florianópolis, 1997.

SOUZA, Rosa Fátima de. Tempos de infância, tempos de escola: a ordenação do tempo escolar no ensino público paulista (1892-1933). Educação e Pesquisa, São Paulo, v. 25, n. 2, jul./dez. 1999.

THOMPSON, E. P. A miséria da teoria ou o planetário de erros (uma crítica ao pensamento de Althusser). Rio de Janeiro: Zahar, 1981, p. 49. 
ANEXO

\begin{tabular}{|c|c|}
\hline Dispositivos legais & Principais assuntos abordados \\
\hline $\mathrm{N}^{\mathrm{o}} 35$ de $14-5-1836$ & $\begin{array}{l}\text { Concurso, ordenado, carreira, conteúdos curriculares, metodologia, } \\
\text { localização das escolas }\end{array}$ \\
\hline $\mathrm{N}^{\mathrm{o}} 136$ de $14-4-1840$ & $\begin{array}{l}\text { Formação de um professor na Escola Normal do Rio de Janeiro, } \\
\text { formação dos professores na escola da Capital, conteúdos curriculares, } \\
\text { inspeção escolar }\end{array}$ \\
\hline No $^{\mathrm{o}} 183$ de $29-4-1843$ & $\begin{array}{l}\text { Habilitação dos professores na escola da Capital, ordenados, } \\
\text { pensionistas para essa escola, punições a professores negligentes, } \\
\text { regras para abrir escola particular, jubilação dos professores }\end{array}$ \\
\hline $\mathrm{N}^{\mathrm{o}} 214$ de $6-5-1845$ & $\begin{array}{l}\text { Conteúdos curriculares, normas do concurso, vencimento dos } \\
\text { professores e professoras, jubilação, valor de aluguel dos edifícios } \\
\text { escolares, licença para abrir escolas particulares, regras para seu } \\
\text { funcionamento }\end{array}$ \\
\hline $\mathrm{N}^{\mathrm{o}} 268$ de $1-5-1848$ & $\begin{array}{l}\text { Criação dos cargos de diretores municipal e paroquial, deveres dos } \\
\text { professores e seus ordenados, jubilações, suspensões, demissões dos } \\
\text { professores, provimento das Cadeiras, disposições gerais }\end{array}$ \\
\hline Resolução no 382 de 1-7-1854 & $\begin{array}{l}\text { Criação dos cargos de diretor e subdiretor em substituição aos } \\
\text { diretores municipais e paroquiais, provimento das Cadeiras, } \\
\text { professores e suas obrigações, exames dos alunos e disposições gerais }\end{array}$ \\
\hline $\begin{array}{l}\text { Regulamento da Instrução } \\
\text { Primária de 05-5-1859 }\end{array}$ & $\begin{array}{l}\text { Divisão do ensino de primeiras letras em quatro anos, divisão dos } \\
\text { conteúdos de acordo com o ano em que o aluno se encontrava, quadro } \\
\text { de horário para cada série, definição de horário para alunos de } 3^{\circ} \text { e } 4^{\circ} \\
\text { anos atuarem como decuriões (monitores), data para exame dos alunos } \\
\text { antes de ingressarem na escola, assim como para o final do ano, } \\
\text { critérios de conduta para os professores, material necessário ao } \\
\text { professor, castigos permitidos para os alunos, feriados e período de } \\
\text { aula }\end{array}$ \\
\hline
\end{tabular}

QUADRO 1 - Principais dispositivos legais da Instrução Primária da Província de Santa Catarina 1836/1860. Quadro elaborado pela autora.

Fonte: Coleção de Leis Provinciais de 1835-1860.

\section{Notas:}

\footnotetext{
${ }^{1}$ Referência aos países do centro do desenvolvimento capitalista, em particular França e Inglaterra, núcleos da revolução política e industrial de fins do século XVIII e início do século XIX que inauguraram uma nova era.

2 Considerando-se a história europeia, é o século XVIII conhecido como "Século das Luzes", mas na realidade brasileira, as ideias iluministas, embora propagadas desde o final daquele século, ganham maior espaço e força no século XIX. São frequentes as referências nos jornais que indicam este último como o "Século das Luzes".
} 
${ }^{3}$ THOMPSON, E. P. A miséria da teoria ou o planetário de erros (uma crítica ao pensamento de Althusser). Rio de Janeiro: Zahar, 1981, p. 49.

4 Durante o século XIX, principalmente durante a década de 1850, foram formadas as principais colônias alemãs de Santa Catarina, e havia, por parte dos dirigentes da província, grande preocupação com essa população. Parte era protestante e mantinha um grande vínculo com o país de origem e, como a religião oficial do Estado brasileiro era a católica, a propagação da fé protestante não atendia a esses preceitos oficiais.

${ }^{5}$ Relatório do presidente da Província, João José Coutinho, apresentado à Assembleia Legislativa em $1^{\circ}$ de março de 1855 .

${ }^{6}$ Embora o editor do jornal tenha utilizado o termo inspetor geral, oficialmente esta função era denominada, em Santa Catarina, naquele período, diretor geral.

${ }^{7}$ SANTA CATARINA, Jornal O Cruzeiro do Sul, de 11 de março de 1858, p. 8.

${ }^{8}$ Relatório geral da instrução pública apresentado por Sérgio Lopes Falcão ao presidente da província, João José Coutinho, em 17 de junho de 1859.

${ }^{9}$ Relatório do Presidente da Província, João José Coutinho, 1859, p 2-3.

${ }^{10}$ SANTA CATARINA, Lei Provincial nº 35, de 14 de maio de 1836.

${ }^{11}$ Circular de José Joaquim Machado de Oliveira, Relatórios da Câmara Municipal ao Presidente da Província 1837/1839.

${ }^{12}$ Fala do Presidente da Província de Santa Catarina, João José Coutinho, em março de 1856, p. 4.

${ }^{13}$ SANTA CATARINA, Coleção de leis provinciais, Resolução 382, de $1^{\circ}$ de julho de 1854, arts. 16 e 17.

${ }^{14}$ Ibidem, art. 45.

${ }^{15}$ Ibidem, arts. 46 e 48.

${ }^{16}$ SANTA CATARINA, O Argos, n. 113, de 6-2-1857, p. 2, c.1. (apud SCHAFASCHECK, R., 1997, p. 129).

${ }^{17}$ SANTA CATARINA, Coleção de leis provinciais, Resolução n: 382, de $1^{\circ}$ de julho de 1854, arts. 32 a 35 .

${ }^{18}$ Relatório do presidente João José Coutinho apresentado à Assembleia Legislativa de Santa Catarina, em março de 1859.

${ }^{19}$ Ofício do presidente João José Coutinho ao diretor geral interino da Instrução Pública, Antônio de Souza Fagundes, 1855.

20 SANTA CATARINA. Ofício do diretor geral interino da Instrução Primária para o presidente da Província, João José Coutinho, 1855.

${ }^{21}$ A distinção entre educar e instruir aparecia sempre que a questão educacional era mencionada. A educação estava voltada à formação geral do homem: valores morais, éticos, religiosos e a instrução aos conhecimentos específicos das diversas áreas do conhecimento.

${ }^{37}$ Relatório do presidente da Província, João José Coutinho, apresentado à Assembleia Legislativa em 1-31850, p. 6.

Recebido em março/2012

Aprovado em outubro/2012 